\title{
The Return Difference between Before and After Issuance of Sharia Bonds (Sukuk)
}

\author{
Sindi Wiranda \\ Universitas Bina Darma \\ Email: wiranda938@gmail.com
}

\begin{abstract}
This study aims to analyze sharia downloading which returns shares on the Indonesian Stock Exchange. This study uses a study program to see the average abnormal returns around the sharia promulgation date (sukuk) and the average difference in abnormal returns before and after sharia withdrawal (sukuk). The population in this study were all sharia negotiations published in the 2014-2019 period. and still published in February 2020. The window period is 60 days $(\mathrm{t}-30$ and $\mathrm{t}+30)$ with a sample of 15 publication events. The method used in this study was the $t$ test and Wilcoxon signed rank test. The results showed that there was an average significant abnormal return around the date of promulgation of sharia (sukuk), namely on the 29th and 1st days before the promulgation of sharia (sukuk). And the results of the Wilcoxon sign rank test show that the significance level is 0.003 , which means that $\mathrm{H} 0$ is accepted so that there is a significant difference in average returns between before and after the announcement of the sharia withdrawal (sukuk) announcement.
\end{abstract}

Keywords: sharia obligation, average abnormal return, event study

\section{Introduction}

According to the fatwa of the National Sharia Council (FDN) in 2002, Islamic bonds are longterm debt securities using the sharia system issued by the issuer to bondholders with a profit sharing system and the repayment of bond funds according to maturity. Since the first issuance of Islamic bonds (sukuk), it has continued to develop with the increasing number of companies issuing Islamic bonds (sukuk).

In the capital market, information can be used as an indicator of the company's development and future risks for investors. Information that comes in can come from within the company (internal) and outside the company (external). Information sourced from within the company (internal) will receive a response from investors with fluctuations in price and trading volume. Meanwhile, information from external sources will receive a response from investors with an increase or decrease in the company's stock price (Sukirno, 2003).

One of the internal information that got reactions from investors was the announcement of the issuance of Islamic bonds (sukuk). If investors view information about the announcement of bond issuance as a consideration in making decisions, then this announcement can result in a shift in prices to a new equilibrium.

PT Adira Dinamika Multifinance Tbk issued a sukuk on 25 June 25 with a mudharabah agreement. The Islamic bonds are worth 42 billion rupiahs with a maturity element of 4 years and a value of 14 billion rupiahs with a maturity of 6 years. From the table of share prices, it can be seen that from the day of issuance up to 4 days after the date of issuance of the Islamic bonds, the share price of PT Adira Dinamika Multifinance has not increased at all and has continued to decline in a short period.

Previous research conducted by Enni Savitri (2015) examined the effect of the issuance of Islamic bonds (sukuk) on market reactions in the Indonesian capital market for the period 2009 
- 2013, showing that the nominal value and rating of Islamic bonds did not have a significant effect on market reactions. while Ibrahim and Minai (2009) show positive results that the issuance of bonds has information (informastion content) which means good news for investors which means that it can provide benefits in the future.

This study aims to determine the effect of Islamic bond issuance announcements on stock returns around the announcement of Islamic bonds (sukuk) issuance and the difference in average abnormal return before and after the issuance of Islamic bonds (sukuk) in companies listed on the IDX and issuing Islamic bonds for the 2014-2019 period.

\section{Literature Review}

Formally the capital market can be defined as the market for various long-term tradable financial instruments (securities), in the form of debt or equity, whether issued by the government, public authorities, or private companies. In the financial market, all forms of debt and equity are traded, both short-term and long-term funds, whether negotiable or not (Husnan, 2005).

According to the language, bonds come from the Dutch language, namely obligate which is standardized into Indonesian into a bond which means "contract". According to Jogiyanto (2010), bonds can be defined as long-term debt that will be paid back at maturity with fixed interest if any. whereas in article 1 of RI Decree No.755 / KMK011 / 1982 states that a bond is a type of securities in the form of a debt acknowledgment letter for borrowing money from the public in a certain form, for a period of at least three years by promising an interest return whose amount and payment have been determined. in advance by the issuer.

The issuance of bonds is a form of company policy that will cause an increase in leverage in the company. For companies, bond issuance is a way of cutting financial intermediation costs in the form of a tax shield. Companies can reduce the share of earnings that must be paid for taxes so that the company can increase the value of the company and provide benefits for shareholders. In other words, investors benefit because they can get higher profits and companies benefit because they can get cheaper costs of funds.

Fauzi, Basyith, Locke and Foo (2015) investigated examine whether Islamic debt characteristics, Islamic debt issuance frequency, Islamic debt type, and firm performance create a wealth effect to shareholders and/or investors when issuing Islamic debt and the results show that for Islamic debt characteristics' impact on stock return reveal that the Islamic debt characteristics, which are debt to equity ratio and firm size, have a positive and significant impact on shareholder wealth, while Islamic debt offering size and maturity have no significant impact on shareholders' wealth for Malaysia. For Indonesia, the result is similar to the result obtained for Malaysia except for debt equity ratio and firm size which have positive and significant impacts. With regards to the frequency and types of Islamic debt issued, only the first issuance of Islamic debt and Islamic debttypes have a positive and significant impact on shareholders' wealth for Malaysia and Indonesia, with exception that there is no debt-type for Indonesia. In terms of the firm value and/or firm financial performance; higher firm value or firm financial performance of firms issuing Islamic debt has a positive and significant impact on shareholders' wealth for Malaysia and Indonesia. Moreover, the study of Islamic bond on return has been investigated by Fauzi, Foo and Basyith (2017) using data from 80 Malaysian firms and 20 Indonesian firms, which span from 2000 to 2009. The data used is the daily closing stock prices for 2 years prior and 1 year after the announcement date using the abnormal return benchmark (mean adjusted return, market adjusted return and market model return). The results 
show that there is a negative and significant impact for both average abnormal returns (AAR) and cumulative average abnormal returns (CAAR) for Malaysia. In contrast to the findings for Malaysia, the impact of Islamic debt announcement is positive and significant for both AAR and CAAR for Indonesia. Further, Malaysia shows an efficient market in the context of weak form efficiency meanwhile Indonesia shows that the market is inefficient in the context of weak form efficiency, which suggests that the price movements are predictable.

Stock is a form of securities traded in the capital market. Shares are securities as a sign of ownership of the issuing company. Shares also mean as a sign of participation or ownership of a person or entity in a public company (Sunariyah, 2004).

Abnormal return (abnormal profit) is the difference between the actual rate of return and the expected return by investors (Jogiyanto Hartono, 2014). The actual rate of return (actual return) is the amount of return realized and can be calculated through historical data. Realized return or actual return is important to note as a measure of company performance and as a basis for determining expected returns and risks that will occur in the future (Hartono A and Wibowo A.J., 2014). The expected return is the return expected by investors in the future (Hartono, 2015).

In connection with the problems to be discussed in this study, a hypothesis is proposed: (1) H1: It is suspected that there is a difference in the average abnormal return before and after the issuance date of Islamic bonds (sukuk); (2) H2: It is suspected that there is an effect of the announcement of the issuance of Islamic bonds on stock returns around the announcement of the issuance of Islamic bonds (sukuk).

\section{Research Method}

This study uses secondary data obtained from stock price data of banking companies that issue Islamic bonds (sukuk) which are listed on the Indonesia Stock Exchange. The sample in this study were companies that issued Islamic bonds (sukuk) for the 2014-2019 period. The variable average abnormal return is seen to determine the average rate of return and market reaction around the issuance date of Islamic bonds (Fauzi, Dencik \& Asiati, 2019). Data collection techniques used in this study, namely by using documentation studies. Documentation studies are carried out by collecting documentary data sources such as historical data on the stock prices of the companies being the research sample. In order to sort out the analytical tools for research, the operational variables in this study are as follows:

Table 1. Variables

\begin{tabular}{|c|c|c|c|}
\hline No & Variables & Definition & Formula \\
\hline 1. & $\begin{array}{l}\text { Average } \\
\text { Abnormal } \\
\text { Return }\end{array}$ & $\begin{array}{l}\text { The average abnormal rate of return } \\
\text { obtained from the actual rate of return with } \\
\text { the level of profit expected by investors }\end{array}$ & $\mathrm{AAR}=\sum \mathrm{Ar}_{\mathrm{i}, \mathrm{t}}$ \\
\hline 2. & $\begin{array}{l}\text { Abnormal } \\
\text { return }\end{array}$ & $\begin{array}{l}\text { The difference between the actual rate of } \\
\text { return and the expected return by investors. }\end{array}$ & $A R_{i, t}=R_{i, t}-E\left[R_{i, t}\right]$ \\
\hline 3. & $\begin{array}{l}\text { Actual } \\
\text { return }\end{array}$ & $\begin{array}{l}\text { The amount of return that is realized and } \\
\text { can be calculated through historical data. }\end{array}$ & $\mathrm{R}_{\mathrm{i}, \mathrm{t}}=\frac{(P i, t)-(P i, t-1)}{P i, t-1}$ \\
\hline 4. & $\begin{array}{l}\text { Expected } \\
\text { return }\end{array}$ & $\begin{array}{l}\text { The return expected by investors in the } \\
\text { future }\end{array}$ & $\mathrm{E}(\mathrm{R})_{, \mathrm{t}}=\frac{I H S G t-I H S G t-1}{\mathrm{IHSGt}-1}$ \\
\hline
\end{tabular}

Data analysis techniques are techniques used to process data in order to get information that is easy to read so that it can be used to find solutions to problems (Sugiyono, 2018). The event 
Study method is a study that examines the impact of information announcements on security prices. Event study research is generally related to how quickly information that enters the market can be reflected in the stock price (Jogiyanto Hartono, 2010). In this case the event observed is the issuance of Islamic bonds (sukuk).

\section{Findings and Discussions}

\subsection{Normality test}

The normality test is used to analyze research data that is normally distributed or not normally distributed. This test uses the Kolmogrov Smirnov test. The results of this normality test will be used to determine the next analysis test, if it is normally distributed, the analysis test used is the Paired Sample T-Test, whereas if it is not normally distributed, the analytical test used is the Wilcoxon Signed Rank Test.

Table 2. Normality Test Results

\begin{tabular}{cccc} 
Normality & Sig & Alpha & Status \\
\hline AAR & 0,00 & 0,05 & Abnormal \\
\hline
\end{tabular}

The results of the normality test show that on 60 days of observation, the significance level is 0.00 , which means that the value is smaller than the value of $\alpha$ or $0.00<\alpha=0.05$. From these results it can be said that the data used were not normally distributed.

\subsection{Wilcoxon Signed Rank Test Results}

The Wilcoxon signed rank test was conducted to determine whether there was a significant difference in average abnormal return between before and after the issuance of Islamic bonds (sukuk) for 60 days of observation. The Wilcoxon Signed rank test results can be seen in the table below

Table 3. Wilcoxon Signed Rank Test

\begin{tabular}{cccc} 
Normality & Sig & Alpha & Status \\
\hline AAR & 0,003 & $\begin{array}{c}\text { Wicoxon signed } \\
\text { rank Test }\end{array}$ & terdapat perbedaan \\
\hline
\end{tabular}

The results of the Wilcoxon signed rank test show that the significance level is 0.003 . This value is smaller than the value of $\alpha=0.05(0.03<0.05)$. This indicates that $\mathrm{H} 0$ is accepted and $\mathrm{Ha}$ is rejected, that is, there is a significant difference in average abnormal return between before and after the announcement of the issuance of Islamic bonds (sukuk).

\subsection{T Test Results}

The $t$ test is conducted to determine whether there is a significant average abnormal return around the announcement date of the issuance of Islamic bonds (sukuk) during the 60 days of observation. The results of the t-test can be seen in the table below:

Table 4 T Test Results

\begin{tabular}{|c|c|c|c|}
\hline Day & AAR & KSE & T Value \\
\hline H-30 & 0,0069 & 0,0191 & 0,3623 \\
\hline H-29 & 0,0125 & 0,0060 & 2,0957 \\
\hline
\end{tabular}




\begin{tabular}{|c|c|c|c|}
\hline H-28 & 0,0022 & 0,0086 & 0,2560 \\
\hline $\mathrm{H}-27$ & 0,0167 & 0,0169 & 0,9903 \\
\hline $\mathrm{H}-26$ & 0,0030 & 0,0485 & 0,0613 \\
\hline H-25 & 0,0026 & 0,0041 & 0,6309 \\
\hline H-24 & $-0,0121$ & 0,0074 & $-1,6293$ \\
\hline $\mathrm{H}-23$ & $-0,0016$ & 0,0027 & $-0,6139$ \\
\hline $\mathrm{H}-22$ & 0,0057 & 0,0086 & 0,6662 \\
\hline $\mathrm{H}-21$ & $-0,0055$ & 0,0086 & $-0,6371$ \\
\hline $\mathrm{H}-20$ & 0,0049 & 0,0035 & 1,3910 \\
\hline H-19 & 0,0036 & 0,0074 & 0,4859 \\
\hline H-18 & $-0,0001$ & 0,0088 & $-0,0148$ \\
\hline $\mathrm{H}-17$ & 0,0009 & 0,0078 & 0,1140 \\
\hline $\mathrm{H}-16$ & $-0,0070$ & 0,0077 & $-0,9082$ \\
\hline $\mathrm{H}-15$ & 0,0078 & 0,0047 & 1,6570 \\
\hline $\mathrm{H}-14$ & $-0,0053$ & 0,0301 & $-0,1753$ \\
\hline $\mathrm{H}-13$ & 0,0052 & 0,0122 & 0,4300 \\
\hline $\mathrm{H}-12$ & $-0,0102$ & 0,0098 & $-1,0374$ \\
\hline $\mathrm{H}-11$ & $-0,0096$ & 0,0054 & $-1,7720$ \\
\hline $\mathrm{H}-10$ & 0,0020 & 0,0223 & 0,0910 \\
\hline H-9 & 0,0117 & 0,0123 & 0,9479 \\
\hline $\mathrm{H}-8$ & $-0,0052$ & 0,0045 & $-1,1474$ \\
\hline $\mathrm{H}-7$ & 0,0098 & 0,0172 & 0,5692 \\
\hline H-6 & 0,0029 & 0,0102 & 0,2869 \\
\hline $\mathrm{H}-5$ & 0,0025 & 0,0031 & 0,8017 \\
\hline $\mathrm{H}-4$ & $-0,0096$ & 0,0225 & $-0,4254$ \\
\hline $\mathrm{H}-3$ & 0,0094 & 0,0277 & 0,3407 \\
\hline $\mathrm{H}-2$ & 0,0089 & 0,0209 & 0,4269 \\
\hline H-1 & 0,0092 & 0,0027 & 3,4102 \\
\hline $\mathrm{H} 0$ & $-0,0787$ & 0,9470 & $-0,0831$ \\
\hline $\mathrm{H}+1$ & 0,5598 & 50,3564 & 0,0111 \\
\hline $\mathrm{H}+2$ & $-0,0146$ & 0,0446 & $-0,3269$ \\
\hline $\mathrm{H}+3$ & $-0,0216$ & 0,0468 & $-0,4615$ \\
\hline $\mathrm{H}+4$ & $-0,0224$ & 0,0455 & $-0,4923$ \\
\hline $\mathrm{H}+5$ & $-0,0334$ & 0,0449 & $-0,7449$ \\
\hline $\mathrm{H}+6$ & $-0,0199$ & 0,0484 & $-0,4113$ \\
\hline $\mathrm{H}+7$ & $-0,0204$ & 0,0516 & $-0,3949$ \\
\hline $\mathrm{H}+8$ & $-0,0183$ & 0,0432 & $-0,4240$ \\
\hline $\mathrm{H}+9$ & $-0,0193$ & 0,0565 & $-0,3413$ \\
\hline $\mathrm{H}+10$ & $-0,0253$ & 0,0689 & $-0,3669$ \\
\hline $\mathrm{H}+11$ & 0,0016 & 0,0480 & 0,0329 \\
\hline $\mathrm{H}+12$ & $-0,0127$ & 0,0569 & $-0,2234$ \\
\hline $\mathrm{H}+13$ & $-0,0156$ & 0,0386 & $-0,4039$ \\
\hline
\end{tabular}




\begin{tabular}{|c|c|c|c|}
\hline $\mathrm{H}+14$ & $-0,0125$ & 0,0544 & $-0,2296$ \\
\hline $\mathrm{H}+15$ & $-0,0225$ & 0,0518 & $-0,4345$ \\
\hline $\mathrm{H}+16$ & $-0,0141$ & 0,0471 & $-0,2987$ \\
\hline $\mathrm{H}+17$ & $-0,0225$ & 0,0514 & $-0,4376$ \\
\hline $\mathrm{H}+18$ & $-0,0302$ & 0,0804 & $-0,3753$ \\
\hline $\mathrm{H}+19$ & 0,0031 & 0,1143 & 0,0269 \\
\hline $\mathrm{H}+20$ & $-0,0194$ & 0,0439 & $-0,4414$ \\
\hline $\mathrm{H}+21$ & $-0,0272$ & 0,0420 & $-0,6483$ \\
\hline $\mathrm{H}+22$ & $-0,0201$ & 0,0448 & $-0,4477$ \\
\hline $\mathrm{H}+23$ & $-0,0189$ & 0,0462 & $-0,4091$ \\
\hline $\mathrm{H}+24$ & $-0,0016$ & 0,0653 & $-0,0248$ \\
\hline $\mathrm{H}+25$ & $-0,0163$ & 0,0488 & $-0,3347$ \\
\hline $\mathrm{H}+26$ & $-0,0097$ & 0,0539 & $-0,1802$ \\
\hline $\mathrm{H}+27$ & $-0,0096$ & 0,0542 & $-0,1772$ \\
\hline $\mathrm{H}+28$ & $-0,0156$ & 0,0497 & $-0,3134$ \\
\hline $\mathrm{H}+29$ & $-0,0155$ & 0,0572 & $-0,2713$ \\
\hline $\mathrm{H}+30$ & $-0,0067$ & 0,0640 & $-0,1042$ \\
\hline
\end{tabular}

The $T$ test results show that during the 60 day observation period there is a significant average abnormal return, namely on the 29th day and the 1st day before the issuance of Islamic bonds (sukuk). The market reaction on $\mathrm{H}-29$ and $\mathrm{H}-1$ is indicated by the t value of (2.0957) on $\mathrm{H}-29$ and (3.4102) on $\mathrm{H}-1>\mathrm{t}$ table $(2,00030)$ with a significance level of $5 \%$. This shows that $\mathrm{H} 0$ is accepted, that is, there is a significant average abnormal return around the date of the announcement of the issuance of Islamic bonds (sukuk), precisely 29 days before and 1 day before the date of issuance of Islamic bonds (sukuk).

\section{Conclusion}

The results of the t-test and Wilcoxon signed rank test analysis that were carried out in this study to determine the effect of the issuance of Islamic bonds (sukuk) on market reactions showed the following results: (1) 1 . There is a significant average abnormal return around the date of issuance of Islamic bonds on D-29 and H-1 before the date of issuance of Islamic bonds (sukuk); (2) 2. There is a significant difference between the average abnormal return between before and after the issuance of Islamic bonds (sukuk).

So it can be explained that average abnormal return affects stock returns in companies that issue Islamic bonds for the 2014-2019 period which are listed on the Indonesia Stock Exchange because investors respond more to this event as good news and the advantages of Islamic bonds that can be captured by investors. If investors want to get higher returns, it is not advisable to invest in Islamic bonds and it is advisable to invest in fields that do not contain sharia principles because the profit rate will be greater because it does not prohibit usury, but if you want to invest with social benefits and get rewarded investors can choose investing in sharia as a form of worship is not just about financial gain.

\section{References}

Fatimatuzzahra, V., \& Herlambang, L. (2014). Reaksi pasar atas Penerbitan Sukuk. JESTT vol.1, $363-378$.

Fauzi, F., Foo, D., \& Basyith, A. (2017). Islamic Bond Announcement: Is There Any Effect on 
Returns? Global Business Review, 18(2), 327-347. https://doi.org/10.1177/0972150916668602 Fauzi, f., Dencik, A. B., \& Diah, I. A. (2019). Metodologi Penelitian untuk Manajemen dan Akuntansi. Jakarta: Salemba Empat.

Fauzi, F., Basyith, A., Locke, S., \& Foo, D. (2015). Islamic bond announcement: The relationship between Islamic debt characteristics and stock return. International Journal of Economic Research, 12(3), 691-717.

Gumanti, T. A., Moelyadi, \& Utami, E. S. (2018). Metode Penelitian Keuangan. jakarta: Mitra Wacana Media.

Hardinanti, N. I., \& Widarjono, A. (2017). Dampak Penerbitan Sukuk dan Obligasi konvensional terhadap return Saham Perusahaan. Jurnal Ekonomi dan Keuangan islam, vol 3, 43 - 51.

Huda, N., \& Heykal, m. (2015). Lembaga Keuangan Islam. Jakarta: Prenada Media.

Mubarok, A., dan Alifiyah (2016). Reaksi pasar atas penerbitan sukuk korporasi (Studi kasus perusahaan yang listing di BEI periode 2007-2014). Tegal: Fakultas Ekonomi Universitas Pancasakti.

Primadani, R. (2013). Reaksi pasar saham terhadap pengumuman penerbitan obligasi syariah di Bursa efek Indonesia. Jurnal ilmu manajemen volume 1, 53 - 62.

Purwaningsih, \& Khoiruddin, M. (2016). Reaksi Pasar Terhadap Pengumuman Penerbitan Sukuk mudharabah dan Obligasi Konvensional. Jurnal Manajemen, 299- 313.

Ramadhani, I. (2013). Pengaruh Penerbitan Obligasi Syariah terhadap Profitabilitas. Jurnal Etikonomi Vol.12, 149-164.

Savitri, E. (2015). Pengaruh penerbitan obligasi syariah (sukuk) terhadap Reaksi Pasar Modal Indonesia Tahun 2009 - 2013. Jurnal Aplikasi Manajemen Vol 13, 689 - 696.

Sukirno. (2003). Event study sebuah pendekatan dalam penelitian akuntansi, Majalah informasi N0.1 ThXXXI : 102-115.

Umam, K. (2013). Pasar modal syariah \& praktik pasar modal syariah. Bandung: CV Pustaka Setia.

Wijayaningtyas, P, dan Wahidahwati (2016). Pengaruh nilai penerbita, rating penerbitan, umur obligasi syariah terhadap reaksi pasar modal. Jurnal Ilmu dan Riset Akuntansi 5 (6), 1-19

\section{Copyrights}

Copyright for this article is retained by the author(s), with first publication rights granted to the journal.

This is an open-access article distributed under the terms and conditions of the Creative Commons Attribution license (http://creativecommons.org/licenses/by/4.0/) 